Article Type: Research Paper

\title{
Analisis Pengaruh Modal Sosial terhadap Produktivitas Usahatani Padi: Studi Kasus Desa Timbulharjo, Kecamatan Sewon, Kabupaten Bantul
}

\author{
Nurul Hikmah ${ }^{1}$, dan Ahmad Maruf ${ }^{1}$
}

\section{굴}

\section{AFILIASI:}

${ }_{1}$ Department of Economics, Faculty of Economics and Business, Universitas Muhammadiyah Yogyakarta, Yogyakarta, Indonesia.

*KORESPONDENSI:

nurul.hikmah.2015@fe.umy.ac.id

ARTIKEL INI TERSEDIA DI:

http://journal.umy.ac.id/index.php/jerss

DOI: 10.18196/jerss.030212

SITASI:

Hikmah, N., \& Maruf, A. (2020). Analisis Pengaruh Modal Sosial terhadap Produktivitas Usahatani Padi: Studi Kasus Desa Timbulharjo, Kecamatan Sewon, Kabupaten Bantul. Journal of Economics Research and Social Sciences, 4(1), 110-117.

\begin{abstract}
Abstrak: Penelitian ini bertujuan untuk mengetahui pengaruh modal sosial terhadap produktivitas usahatani padi di Desa Timbulharjo, Kecamatan Sewon, Kabupaten Bantul. Penelitian ini dilaksanakan di Desa Timbulharjo, Kecamatan Sewon, Kabupaten Bantul sebanyak 103 sampel. Alat analisis yang digunakan dalam penelitian adalah analisis regresi berganda. Penelitian ini menggunakan metode kualitatif dengan analisis statistik deskriptif, dimana data yang digunakan adalah data primer yang didapat dengan menggunakan kuesioner (angket). Alat analisis yang digunakan adalah analisis regresi berganda. Hasil penelitian menunjukkan rata-rata tingkat produktivitas usahatani padi di Desa Timbulharjo, Kecamatan Sewon, Kabupaten Bantul berada pada kategori sedang. Variabel yang mempengaruhinya adalah: kepercayaan, partisipasi, jaringan, norma sosial berpengaruh signifikan terhadap produktivitas usahatani padi, dan variabel berbagi informasi tidak berpengaruh signifikan produktivitas usahatani padi. Kata Kunci: Modal Sosial; Kepercayaan; Jaringan; Norma Sosial; Produktivitas Padi.
\end{abstract}

\section{Pendahuluan}

Indonesia merupakan Negara agraris yang kaya akan sumber daya alam (SDA). Potensi tersebut penting untuk program pembangunan terutama di daerah pedesaan yang mayoritas masyarakatnya bekerja pada sektor pertanian. Dengan kondisi yang demikian, sumber daya fisik yang utama dan terpenting adalah tanah (lahan pertanian). Termasuk lahan yang ada di daerah pedesaan umumnya digunakan untuk kehidupan sosial dan kegiatan ekonomi. Kegiatan sosial di antaranya berkeluarga, bersekolah, beribadah, berekreasi, berolah raga, dan sebagainya. Sedangkan penggunaan lahan untuk kegiatan ekonomi di antaranya kegiatan ekonomi pada bidang pertanian, perkebunan, perternakan, kehutanan, perindustrian, dan sebagainya (Aziz, 2017).

Modal sosial sebagai serangkaian nilai-nilai atau norma-norma informal yang dimiliki para anggota kelompok, diwujudkan dalam perilaku yang memungkinkan terjalinnya kerjasama secara efisien dan efektif untuk keuntungan bersama (Rohmani dkk, 2015). Modal sosial telah diyakini mampu memberikan dampak yang besar bagi masyarakat dan anggotanya. Sebagaimana yang disampaikan oleh Bank Dunia, yang meyakini bahwa modal sosial merujuk pada dimensi institusional, 
hubungan-hubungan yang tercipta, dan norma-norma yang membentuk kualitas serta kuantitas hubungan sosial dalam masyarakat, dan sebagai perekat yang menjaga kesatuan anggota kelompok secara bersama-sama (Cahyono \& Adhiatma, 2018).

Modal sosial juga merupakan faktor penting yang perlu dimiliki petani untuk melakukan inovasi. Penggunaan teknologi dan pembuatan inovasi dalam seluruh rangkaian kegiatan yang pertanian akan lebih efektif apabila dilakukan dalam bentuk kelompok dan dilakukan secara kolektif. Pemanfaatan teknologi dan inovasi seringkali disalurkan oleh lembaga dalam satu kelompok dimana kelompok yang dibentuk atas dasar kesamaan tujuan dan ikatan kekeluargaan. Tanpa ikatan modal sosial, kelompok diantara sesama pelaku pertanian dan pelaksanaan kegiatan ini akan sulit dilakukan dimana kerjasama dan kepercayaan diantara para pelaku pertanian menjadi hal yang paling utama. Demikian halnya apabila ada rasa percaya antar sesama petani dalam pemanfaatan tenaga kerja, maka proses produksi menjadi lebih efisien. Jika modal sosial di suatu kelompok atau masyarakat semakin menghilang maka segala macam bentuk kebijakan dari pemerintah dengan tujuan ingin mensejahterakan petani akan sulit untuk terealisasikan (Kholifah, 2016).

Daerah Istimewa Yogyakarta merupakan salah satu daerah yang menghasilkan tanaman pangan yaitu padi. Produksi padi terbesar di Daerah Istimewa Yogyakarta salah satunya ada di wilayah Kabupaten Bantul. Pada saat ini luas panen dan produksi padi di Kabupaten Bantul cenderung fluktuatif. Hal ini bisa dilihat dari jumlah luas panen dan jumlah produksi secara keseluruhan tiap tahun yang berubah-ubah.

Tabel 1 Perkembangan Luas Panen, Produksi, dan Produktivitas Padi Sawah di Bantul Tahun 2012-2016

\begin{tabular}{lcccccc}
\hline \multicolumn{1}{c}{ Kategori } & $\mathbf{2 0 1 2}$ & $\mathbf{2 0 1 3}$ & $\mathbf{2 0 1 4}$ & $\mathbf{2 0 1 5}$ & $\mathbf{2 0 1 6}$ & $\begin{array}{c}\text { Rata-rata Pertumbuhan } \\
\text { (\%) }\end{array}$ \\
\hline $\begin{array}{l}\text { Luas Panen } \\
\text { (Ha) }\end{array}$ & 30,064 & 32,621 & 30,160 & 29,522 & 29,944 & 0.07 \\
$\begin{array}{l}\text { Produksi } \\
\begin{array}{l}\text { (Ton) } \\
\text { Produktivitas } \\
\text { (Ku/Ha) }\end{array}\end{array}$ & 204,959 & 209,149 & 192,711 & 198,456 & 180,362 & -2.99 \\
\hline
\end{tabular}

Sumber: Dinas Pertanian Provinsi Yogyakarta

Pada tabel 1 luas panen padi sawah di Bantul dari tahun 2012 sampai 2016 pengalami fluktuasi. Luas panen padi sawah pada tahun 2012 sebesar 30,064 Ha, pada tahun 2013 luas panen padi sawah mengalami peningkatan sebesar 32,621 $\mathrm{Ha}$. Luas panen padi sawah pada tahun 2014 menurun sebesar 30,160 Ha, pada tahun 2015 luas panen padi sawah kembali mengalami penurunan sebesar 29,522 Ha, tahun 2016 luas panen padi meningkat sebesar 29,944, dan rata-rata pertumbuhan sebesar 0.07 persen. Produksi padi sawah tahun 2012 sampai 2016 mengalami fluktuasi dan rata-rata pertumbuhan menurun sebesar 2,99 persen. Produktivitas padi sawah tahun 2012 sebesar 68,17 $\mathrm{Ku} / \mathrm{Ha}$, pada tahun 2013 dan 2014 produktivitas padi sawah mengalami penurunan. Produktivitas padi sawah pada tahun 2015 mengalami peningkatan sebesar 67,22 $\mathrm{Ku} / \mathrm{Ha}$, namun pada tahun 2016 produktivitas padi sawah kembali mengalami 
penurunan sebesar $60,3 \mathrm{Ku} / \mathrm{Ha}$, dan rata-rata pertumbuhan menurun sebesar 2.87 persen.

Desa Timbulharjo merupakan salah satu Desa yang ada di Kecamatan Sewon, Kabupaten Bantul. Letak Desa Timbulharjo berada di daerah yang letak topografis tanah yang rata dan subur sehingga, sebagian besar lahannya dimanfaatkan oleh masyarakat untuk lahan pertanian. Mata pencaharian masyarakat Desa Timbulharjo adalah petani. Namun demikian, Desa Timbulharjo mengalami masalah yang begitu besar karena semakin berkurangnya lahan pertanian. Hal ini dikarenakan mengalami alih fungsi, baik untuk permukiman maupun fasilitas umum seperti sekolah, perkantoran, pabrik, hotel dan tempat wisata.

Konsep modal sosial menawarkan betapa pentingnya suatu hubungan satu sama lain, dan memeliharanya agar terus terjalin, setiap individu dapat bekerjasama untuk memperoleh hal-hal yang belum tercapai sebelumnya serta meminimalisasikan kesulitan yang besar. Berdasarkan uraian tersebut, maka peneliti tertarik untuk meneliti seberapa besar modal sosial yang ada pada petani di desa Timbulharjo, Kecamatan Sewon, Kabupaten Bantul kemudian pengaruhnya terhadap produktivitas petani. Diharapkan dengan adanya hasil penelitian ini pemerintah di daerah khususnya Kecamatan Sewon Desa Timbulharjo dapat menerapkan strategi peningkatan produktivitas petani.

\section{Tinjauan Pustaka}

Dalam penelitian yang dilakukan oleh Ulinnuha (2012), ia mencoba menganalisis strategi peningkatan produktivitas petani melalui penguatan modal social dengan menggunakan metode gabungan kuantitatif dan kualitatif. Hasil penelitian ini yakni, modal sedikit banyak memberikan solusi dari jalan keluar atas permasalahan yang ada. Dalam penelitian yang dilakukan oleh Widodo dan Sugiyanto (2015), peneliti menggunakan metode analisis kuantitatif melalui regresi linear berganda. Hasil penelitian menunjukkan bahwa variabel modal sosial dapat mengakselerasi produktivitas lahan jagung secara postitif walaupun tidak signifikan. Malik (2015) juga melakukan penelitian yang sama mengenai modal sosial petani cengkeh dalam mendukung usaha pertanian tanaman cengkeh. Penelitian ini menggunakan pendekatan deskriptif kuantitatif. Hasil penelitian menunjukkan bahwa modal sosial yang dimiliki petani cengkeh berupa jaringan, kepercayaan, nilai serta norma sosial, jaringan sosial berkontribusi besar terhadap produktivitas usahatani.

Penelitian yang dilakukan oleh Ariyanti dan Arsyad (2008) di Batang, Jawa Tengah. Penelitian ini menggunakan data primer yang diperoleh dari penyebaran kuesioner. penelitian ini dilakukan untuk mengetahui pengaruh dari modal sosial terhadap produktivitas tenaga kerja di PT. Pagilaran dengan menggunakan analisis regresi berganda. Hasil dari penelitian menyimpulkan bahwa dari total tujuh variabel independen yang digunakan, ternyata tidak semuanya berpengaruh secara signifikan terhadap variabel dependen berupa produktivitas tenaga kerja. 


\section{Metode Penelitian}

Metode penelitian yang digunakan dalam penelitian ini menggunakan pendekatan deskriptif kualitatif dan kuantitatif. Jenis data yang digunakan dalam penelitian ini adalah data primer dan data sekunder. Objek dalam penelitian ini adalah Desa Timbulharjo, Kecamatan Sewon, Kabupaten Bantul. Subjek dari penelitian ini adalah masayarakat yang berprofesi sebagai petani.

Adapun dalam penelitian ini teknik pengambilan sampel yang digunakan diambil dengan menggunakan perhitungan rumus slovin. Tingkat kesalahan yang di toleransi yaitu 10 persen. Dengan demikian total sampel yang dihasilkan yaitu 97,63 sehingga dibulatkan menjadi 103 sampel dengan taraf kesalahan yang mungkin terjadi tidak lebih dari 0,1 atau 10 persen. Jadi total populasi dalam penelitian ini adalah sebanyak 103 petani Desa Timbulharjo, Kecamatan Sewon, Kabupaten Bantul.

\section{Hasil dan Pembahasan}

Berdasarkan hasil Uji Validitas yang telah dilakukan, seluruh nilai koefisien pada pernyataan yang diajukan lebih besar dari nilai r-tabel dengan signifikan 0,05 yang nilainya 0,163 , dengan demikian pernyataan semua nomor dianggap valid, sebab nilai koefisien $>0,163$.

Selanjutnya, Uji Reliabilitas dilakukan untuk menetapkan apakah instrumen dalam penelitian ini kuesioner dapat digunakan lebih dari satu kali, paling tidak oleh responden yang sama akan menghasilkan data yang konsisten (Basuki \& Yuliadi, 2015). Dari semua variabel yang sudah di uji, ternyata memiliki nilai Cronbach's Alpha $>0,70$, yang berarti dari kelima instrument dinyatakan reliabel atau sudah memenuhi persyaratan.

Uji tahap kedua yakni, Uji Asumsi Klasik. Dalam uji ini, terdapat beberapa tahapan, yang pertama yakni, Uji normalitas untuk menentukan data yang telah dikumpulkan berdistribusi normal atau diambil dari populasi normal (Basuki \& Yuliadi, 2015). Dengan demikian, uji normalitas nilai asymp.sig 0,200>0,05 sehingga dapat disimpulkan bahwa data berdistribusi normal.

Yang kedua, Uji multikolinearitas untuk melihat hubungan linear antara variabel bebas $\mathrm{X}$ dalam model regresi berganda. Uji multikolinearitas dapat dideteksi dengan melihat nilai Variance Inflation Factors (VIF). Dengan demikian bahwa nilai varience inflation factor (VIF) pada seluruh variabel mempunyai nilai kurang dari 10,00 dan nilai tolerance pada tiap variabel mempunyai nilai lebih dari 0,10. Maka dapat disimpulkan bahwa tidak adanya korelasi yang tinggi antar variabel atau seluruh variabel bebas dari gejala multikolinearitas.

Uji yang tidak kalah pentingnya adalah Heteroskedastisitas, dalam model regresi penelitian ini, nilai signifikan lebih dari 0,05 yaitu variabel kepercayaan (trust) sebesar 0,675 , variabel partisipasi (participation) sebesar 0,240, variabel jaringan (network) 
sebesar 0,627, variabel norma sosial (social norms) sebesar 0,620 dan variabel berbagi informasi (sharing information) sebesar 0,102 . Hal ini menyatakan bahwa variabel yang dipakai dalam model regresi tidak terindikasi gejala heteroskedastisitas.

Untuk melihat apakah hipotesis pada penelitian ini benar adanya, penulis melanjutkan pengujian dengan menggunakan Uji t parsial. Hal ini dilakukan untuk mengetahui pengaruh secara parsial antara variabel independen yaitu kepercayaan (trust), partisipasi (participation), jaringan (network), norma sosial (social norm), dan berbagi informasi (sharing information) dengan variabel dependen yaitu produktifitas usahatani padi.

Tabel 2 Hasil Uji T Statistic

\begin{tabular}{lccccc}
\hline \multicolumn{1}{c}{ Variabel } & T Hitung & T Tabel & $\begin{array}{c}\text { Standardized } \\
\text { Coefficients }\end{array}$ & Sig. & Hasil \\
\hline Kepercayaan & 2,192 & 1,984 & 0,210 & 0,031 & Signifikan \\
Partisipasi & 2,044 & 1,984 & 0,181 & 0,044 & Signifikan \\
Jaringan & 2,116 & 1,984 & 0,205 & 0,037 & Signifikan \\
Norma sosial & 2,114 & 1,984 & 0,198 & 0,037 & Signifikan \\
Berbagi Informasi & 1,910 & 1,984 & 0,163 & 0,059 & Signifikan \\
\hline
\end{tabular}

Sumber: Data Primer, diolah 2019

Berdasarkan hasil pengolahan data pada table 2, hasilnya menunjukan bahwa nilai thitung sebesar 2,192 dan nilai t-tabel sebesar 1,984 sehingga 2,192>1,984. Sedangkan nilai signifikan kurang dari 0,05 , sehingga dapat disimpulkan bahwa kepercayaan berpengaruh positif signifikan terhadap produktivitas. Rasa percaya antar petani didalam kelompok tani dapat memfasilitasi peningkatan produktivitas secara tidak langsung. Hal ini sesuai dengan teori menurut Knack dan Keefer (1997) rasa percaya yang tinggi antar sesama petani akan membuat kondisi sosial yang aman. Kondisi tersebut menyebabkan petani tidak perlu menambah biaya untuk membayar sumber daya manusia untuk menjaga faktor-faktor produksi yang dimiliki. Dengan demikian dapat dikatakan bahwa Kepercayaan berpengaruh secara positif terhadap produktivitas. Hal ini juga sesuai dengan penelitian Trisnanto, Fitriani, dan Fatih (2017) yaitu dalam penelitian ini nilai kepercayaan, anggota Gapoktan percaya terhadap pengurus kelompok. Mereka percaya pengurus Gapoktan akan bekerja secara bertanggung jawab dan akan memperjuangkan tujuan Gapoktan. Unsur keterbukaan ditunjukkan oleh transparansi dalam pengelolaan program kegiatan/bantuan pengurus Gapoktan. Dengan demikian dapat dikatakan bahwa kepercayaan berpengaruh secara positif terhadap pertanian.

Dengan nilai t-hitung sebesar 2,044 dan nilai t-tabel sebesar 1,984 sehingga $2,044>1,984$. Sedangkan nilai signifikan kurang dari 0,05, sehingga dapat disimpulkan bahwa partisipasi berpengaruh positif signifikan terhadap produktivitas padi. Hal ini juga sesuai dengan penelitian yang sudah dilakukan oleh Widodo dan Sugiyanto (2015), ia menyimpulkan bahwa partisipasi dalam asosiasi sukarela merupakan faktor kunci dari modal sosial, karena di dalam partisipasi sosial akan terjadi interaksi antar anggota kelompok. Interaksi-interaksi yang terjadi seperti pertukaran ide, informasi, pengetahuan dan gagasan serta merumuskan cara mencari solusi sebuah masalah yang 
sedang dialami oleh kelompok tersebut. Dapat diambil kesimpulan bahwa di dalam interaksi sosial terjadi pertukaran ide, informasi dan pengetahuan yang pada akhirnya bermuara pada inovasi yang akan meningkatkan produktivitas. Dengan demikian, dapat dikatakan bahwa partisipasi berpengaruh terhadap produktivitas lahan jagung.

Variabel jaringan muncul dengan nilai t-hitung sebesar 2,116 dan nilai t-tabel sebesar 1,984 sehingga $2,116>1,984$. Sedangkan nilai signifikan kurang dari 0.05 , sehingga dapat disimpulkan bahwa jaringan berpengaruh positif signifikan terhadap produktivitas padi. Hal ini sesuai dengan penelitian Aziz (2017) yang mengatakan bahwa modal sosial dari aspek jaringan akan mempengaruhi tingkat produktivitas. Semakin banyak penguasaan informasi dan meluas yang dimiliki maka akan semakin tinggi tingkat produktivitas yang dimiliki. Hal itulah yang menjadi modal utama dalam rangka memajukan produktivitas. Penelitian Busthanul, Kamaluddin, Heliawaty, dan Saputra (2016) dan Trisnanto, dkk (2017) juga mengatakan bahwa variabel jaringan berpengaruh positif terhadap usahatani.

Berdasarkan hasil pengolahan data menunjukan bahwa nilai t-hitung sebesar 2,114 dan nilai t-tabel sebesar 1,984 sehingga 2,114>1,984. Sedangkan nilai signifikan kurang dari 0,05, maka dapat disimpulkan bahwa norma sosial berpengaruh positif signifikan terhadap produktivitas padi. Hal ini sesuai dengan penelitian yang sudah dilakukan oleh Kholifa (2016) \& Aziz (2017), mereka mengatakan bahwa semakin tinggi tingkat norma sosial maka semakin tinggi produktivitas petani. Hal ini juga berlaku untuk hal sebaliknya yaitu jika norma sosial rendah maka semakin rendah produktivitas petani.

Berdasarkan hasil pengolahan data menunjukan bahwa nilai t-hitung sebesar 1,910 dan nilai t-tabel sebesar 1,984 sehingga $1,910<1,984$, nilai signifikan kurang dari 0.05 , sehingga dapat disimpulkan bahwa berbagi informasi berpengaruh positif signifikan terhadap produktivitas petani. Hal ini sesuai dengan penelitian yang dilakukan oleh Busthanul, dkk (2016) yang menyatakan bahwa secara umum dari hasil penelitian ini dapat dikatakan bahwa peran sharing information pada modal sosial petani tergolong tinggi.

Untuk mengetahui apakah variabel kepercayaan, partisipasi, jaringan, norma social, dan berbagi informasi mempunyai pengaruh yang signifikan terhadap variabel produktivitas padi. Maka perlu dilakukan Uji F. Berdasarkan pengujian menggunakan alat analisis regresi linier berganda maka dapat dilihat sebagai berikut:

Tabel 3 Hasil Uji F

\begin{tabular}{lcccc}
\hline \multicolumn{1}{c}{ Variabel } & F Hitung & F Tabel & Sig. & Hasil \\
\hline Kepercayaan & 38,682 & 2,31 & 0,000 & Signifikan \\
Partisipasi & 38,682 & 2,31 & 0,000 & Signifikan \\
Jaringan & 38,682 & 2,31 & 0,000 & Signifikan \\
Norma sosial & 38,682 & 2,31 & 0,000 & Signifikan \\
Berbagi informasi & 38,682 & 2,31 & 0,000 & Signifikan \\
\hline
\end{tabular}

Sumber: Data Primer, diolah 2019 
Berdasarkan hasil dari uji f pada tabel 3, dengan f-hitung sebesar 38,682 dan f-tabel sebesar 2,31 dengan signifikan 0,000<0,05, maka dapat disimpulkan bahwa seluruh variabel secara bersama-sama mempengaruhi produktivitas petani.

Tabel 1.4 Hasil Uji Koefisien Determinasi

\begin{tabular}{|c|c|}
\hline Variabel & Adjusted $R^{2}$ \\
\hline Kepercayaan & 0,649 \\
\hline Partisipasi & 0,649 \\
\hline Jaringan & 0,649 \\
\hline Norma sosial & 0,649 \\
\hline Berbagi Informasi & 0,649 \\
\hline
\end{tabular}

Sumber: Data Primer, diolah 2019

Berdasarkan tabel 4, dapat disimpulkan bahwa besarnya koefisien 0,649 dari varian dapat dijelaskan dengan variabel di dalam model. Sedangkan, 35,1 persen sisanya dipengaruhi oleh variabel lain di luar model.

\section{Kesimpulan}

Berdasarkan hasil analisis di atas, dapat disimpulkan bahwa tingkat kepercayaan, tingkat partisipasi, tingkat jaringan, tingkat norma sosial berpengaruh positif terhadap produktivitas usaha tani pada Desa Timbulharjo. Sedangkan, tingkat berbagi informasi tidak. Berdasarkan hasil yang didapatkan, diharapkan tingkat kepercayaan kepada sesama petani lebih ditingkatkan lagi, karena manfaat rasa saling mempercayai antar sesama petani di dalam suatu kelompok sangat menentukan kerjasama antar anggota yang pada akhirnya akan menentukan hasil dari output suatu kelompok. Selain itu, Partisipasi petani dalam kegiatan harus lebih ditingkatkan, sehingga mampu membentuk dan menumbuh kembangkan kelompok tani secara partisipatif. Jaringan petani juga sangat penting untuk ditingkatkan lagi, sehingga akan tumbuh kerjasama yang kompak dan serasi, ketaatan terhadap norma sosial.

\section{Daftar Pustaka}

Ariyanti, Z, K., \& Arsyad, L. (2008). Pengaruh Modal Sosial terhadap Produktivitas Tenaga Kerja: Studi Kasus PT. Pagilaran, Batang, Jawa Tengah. Tesis. Universitas Gadjah Mada.

Aziz, B. W. (2017). Modal Sosial Petani dalam Peningkatan Produktifitas Pertanian di Kelurahan Biraeng Kecamatan Minasate'ne Kabupaten Pangkep. Tesis. Universitas Hasanuddin. Makassar.

Basuki, A. T., \& Yuliadi, I. (2015). Elektronic Data Processing (SPSS 15 dan Eviens 7). Yogyakarta: Danisa Media.

Busthanul, N., Kamaluddin, A., Heliawaty, H., \& Saputra, M. T. (2016). Modal Sosial: Peran, Unsur, dan Pengaruhnya Terhadap Usahatani Padi “Pulu Mandoti” Di Enrekang. Prosiding Seminar Nasional Hasil Penelitian.

Cahyono, B., \& Adhiatma, A. (2019). Peran Modal Sosial Dalam Peningkatan Kesejahteraan Masyarakat Petani Tembakau di Kabupaten Wonosobo. Conference In Business, 
Accounting, And Management (CBAM). 1(1), 131-144. Diakses dari http://jurnal.unissula.ac.id/index.php/cbam/article/view/128

Kholifa, N. (2016). Pengaruh modal sosial terhadap produktivitas petani (Studi kasus di Kecamatan Cilacap Utara Kabupaten Cilacap). Jurnal Pendidikan dan Ekonomi, 5(2), 89-97. Diakses dari http://journal.student.uny.ac.id/ojs/index.php/ekonomi/article/view/3984

Knack, S., \& Keefer, P. (1997). Does Social Have an Economic Payoff? A Cross-Country Investigation. Quarterly Journal of Economics, 112(4), 1251-1288. Diakses dari http://www.socialcapitalgateway.org/sites/socialcapitalgateway.org/files/data/pape r/2011/07/28/rknackandkeefer1997-doessocialcapitalhaveaneconomicpayoffaje.pdf

Malik, I. (2015). Modal Sosial Petani Cengkeh Dalam Mendukung Usaha Pertanian Tanaman Cengkeh. Skripsi. Universitas Negeri Semarang.

Trisnanto, T. B., Fitriani, F., \& Fatih, C. (2017). Membangun modal sosial pada gabungan kelompok tani. Masyarakat, Kebudayaan dan Politik, 30(1), 59-67. http://dx.doi.org/10.20473/mkp.V30I12017.59-67

Ulinnuha, M. Z. (2012). Strategi Peningkatan Produktivitas Petani Melalui Penguatan Modal Sosial. Skripsi. Semarang: Program Sarjana Fakultas Ekonomika dan Bisnis Universitas Diponegoro.

Widodo, K., \& Sugiyanto, F. (2015). Analisis Pengaruh Modal Sosial Terhadap Produktivitas Lahan Jagung (Studi Kasus: Kecamatan Pulokulon, Kabupaten Grobogan). Skripsi, Fakultas Ekonomika dan Bisnis Universitas Diponegoro. 